\title{
An Analysis of Impacts of Currency Devaluation on Economic Growth in Vietnam in 2000-2012
}

\section{NGUYẼ̃N MINH HẢI}

Quang Trung University

Email: minhhai.nguyen77@gmail.com

\section{PHAN TẤT HIỂN}

Saigon University

Email: hienphantat18@gmail.com

\section{ĐẬNG HUYỀN LINH}

Development Strategy Institute, MPI

Email: linh_dh@yahoo.com

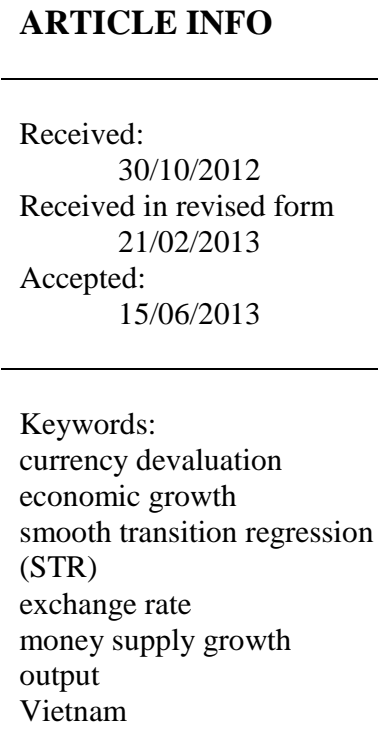

\section{ABSTRACT}

The paper aims at exploring effects of currency devaluation on Vietnam's economic growth. Our approach is to employ smooth transition regression (STR) to estimate relationship between real exchange rate, money supply, and public expenditure with Vietnam's GDP in 2000-2012. The results show that currency devaluation can increase output if growth of money supply is less than $24.46 \%$, and it may produce negative effects on the output when the money supply grows higher than the above threshold.

Keywords:

currency devaluation

economic growth

smooth transition regression

(STR)

money supply growth

Vietnam 


\section{INTRODUCTION}

Currency devaluation is usually used for improve balances of trade and of payments on current accounts and increase foreign exchange reserves. Although it is generally agreed that currency devaluation is an important instrument for adjusting external imbalances, there is controversy about whether currency devaluation supports economic growth.

This paper aims at analyzing impacts of currency devaluation on Vietnam's economic growth in 2000-2012. More precisely, authors employ STR to explore reaction of output to fluctuations in exchange rate. The approach can clarify the conditions which show that currency devaluation results in decreasing or increasing output depending on the rate of growth of money supply.

\section{METHODOLOGY AND APPLICATION OF MODEL}

\section{a. Methodology:}

The traditional theories of trade, such as Marshall - Lerner conditions and J-curve effect, demonstrate that currency devaluation may improve balances of trade due to cheaper exports and dearer imports. Neo-Keynesian theories posit that increasing net export is an important factor in promoting domestic production, generating demand for labor, growing demand for consumer goods and investment, and increasing economic output finally. Currency devaluation, in other words, can recover the external imbalances and impact positively on the economic growth. However, various economic arguments and quantitative evidence show that currency devaluation has negative influences on the growth via several channels, as discussed in detail by Bahmani-Oskooee \& Miteza (2003):

- Currency devaluation will increase prices of imports and lead to inflation, which will contract aggregate domestic demand. Moreover, higher spending on imported intermediate products decreases positive impact of currency devaluation on trade balance.

- Currency devaluation may reduce investment in fixed assets because developing countries usually have to import capital goods. The effect will be more serious if imported capital goods represent a high percentage of the gross investment.

- Inflation caused by currency devaluation increases interest rate and wages, which lead to higher input costs for manufacturing enterprises.

- Burden of debt service and repayment to foreign debts may be heavier when currency is devaluated, which may reduce resources for consumption and production.

Interwoven positive and negative impacts of currency devaluation on economic growth make analyses and quantification of these impacts are extremely complicated. Bahmani- 
Oskooee \& Miteza (2003) find that four approaches which are used for analyzing impacts of currency devaluation on economic growth include:

- Before-after approach compares output performance of a group of countries for three years before and after currency devaluation. Its biggest limitation is the failure to produce an estimate of individual impact of devaluation on output.

- The control-group approach compares before-after output performance in devaluing countries with output performance in a set of non-devaluing countries (the control group) during the same time span. Since this method assumes that both devaluing and control group countries face the same external factors, the difference in the output performance of these two groups should only reflect the effect of devaluations. Although this approach outperforms the before-after method, many economists maintain that comparison of devaluing with non-devaluing countries is not satisfactory because most devaluing countries are always less developed than non-devaluing ones.

- Macro-simulation approach: using macro econometric models or computable general equilibrium models to simulate impacts of devaluation on output. Advantage of this approach is to provide many macroeconomic analyses, especially a mechanism that transmits the impact of devaluation on output as well as other macroeconomic variables. However, constructing models of this type is extremely costly and complicated.

- Econometric modeling: Econometric models used for analyzing impact of currency devaluation on output include estimation of panel data for a group of countries, time series models, SVAR, VECM, and smooth transition regression (STR) (Terasvirta, 2004). Output is the variable explained in those models, and explanatory variables may be real exchange rate, nominal exchange rate, government spending, the ratio of government expenditure to GDP, money supply, term of trade, exports, imports, interest rate, output gap, unemployment rate, the price of crude oil, etc.

\section{b. Econometric Model:}

Econometric model used for examining impacts of currency devaluation on economic growth in Vietnam is based on Edwards' model (Edwards, 1989). Model's equation is written as:

$$
\log \mathrm{Y}=\mathrm{a}_{0}+\mathrm{a}_{1} \log \mathrm{E}+\mathrm{a}_{2} \log \mathrm{M}+\mathrm{a}_{3} \log \mathrm{G}+\mathrm{u}(1)
$$

where $\mathrm{Y}$ is output or GDP at current price, G and M represent government expenditure and money supply respectively, and $\mathrm{E}$ is devaluation rate of the real exchange rate. Coefficient $\mathrm{a}_{1}$ denotes the elasticity of output with respect to exchange rate (its sign and magnitude indicate the effect of devaluation on output). Since exchange rate is defined as a 
unit of domestic currency per unit of international currency, a negative coefficient of exchange rate implies that devaluation is reducing the output, and vice versa with a positive coefficient. Coefficient $\mathrm{a}_{2}$ and $\mathrm{a}_{3}$ both are expected to bear positive signs and denote the impact of money supply and fiscal policy respectively on the output.

Equation (1) can be estimated by using STR. The non-linear form of this equation is as follows:

$\log \mathrm{Y}=\mathrm{a}_{0}+\mathrm{a}_{1} \log \mathrm{E}+\mathrm{a}_{2} \log \mathrm{M}+\mathrm{a}_{3} \log \mathrm{G}+\left[\mathrm{a}_{0}{ }_{0}+\mathrm{a}^{*}{ }_{1} \log \mathrm{E}+\mathrm{a}^{*}{ }_{2} \log \mathrm{M}+\mathrm{a}_{3}{ }_{3} \log \mathrm{G}\right] \mathrm{G}(\mathrm{st}, \gamma, \mathrm{c})+\varepsilon_{\mathrm{t}}$

where $\mathrm{a}_{1}, \mathrm{a}_{2}$, and $\mathrm{a}_{3}$ are parameters in model's linearity, $\mathrm{a}^{*}{ }_{1}, \mathrm{a}^{*}$, and $\mathrm{a}^{*}{ }_{3}$ are parameters in model's non-linearities and $\varepsilon_{t} \sim i i d\left(0, \sigma_{u}^{2}\right)$.

$$
\text { Transition function } G\left(\gamma, c, s_{t}\right)=\left(1+\exp \left\{-\gamma \prod_{k=1}^{K}\left(s_{t}-c_{k}\right)\right\}\right)^{-1}, \quad \gamma>0 \text { is a function of }
$$

continuous transition variable $\mathrm{s}_{\mathrm{t}}$ bound between 0 and 1 and depends on transition variable $\mathrm{s}_{\mathrm{t}}$, threshold parameter $\mathrm{c}$, and slope parameter $\gamma$. Vectors $\phi$ and $\theta$ represent parameters in linearities and nonlinearities of corresponding model. The transition function $\mathrm{G}$ might be monotonous or symmetric depending on $\mathrm{k}=1$ or $\mathrm{k}=2$ in the transition function. If $\mathrm{k}=1$ the model is called LSTR1 with only one threshold, and transition between two states is monotonous. If $\mathrm{k}=2$ (LSTR2), there will be an upper and lower thresholds between two states.

The process of modeling STR consists of three stages as specification, estimation and evaluation (Terasvirta, 2004). The specification stage aims at testing nonlinearity of the linear model (1), thereby selecting a specific transition variable and a specific model (LSTR1 or LSTR2) for non-linear estimation.

\section{RESULT OF STR MODEL ESTIMATION FOR IMPACT OF CURRENCY DEVALUATION ON THE GROWTH}

Authors use time series data set of quarterly basis and 71 observations, from Q1/1995 to Q3/2012, for the variables included in Equation (2). GSO Department of National Account System estimates CPI, GDP data and government expenditure at comparing price. The data of money supply and exchange rates of Vietnam and CPI of the USA, are taken from IMF International Financial Statistic (IFS). The real exchange rate, in this research, is only the rate of the VND to the US dollar. To fully estimate impacts of endogenous variables (real exchange rate and money supply) on the growth, the selected lag for these variables is 4 and lag for the exogenous variable (governmental spending) is 2 . All variables are turned into 
first difference of the natural logarithm because all variables in the estimation equation (2) are non-stationary time series.

Because the research focuses on possible non-linear relationships and asymmetric effects of currency devaluation on the growth, the first step to take is conducting linear tests of equation (1) according to aforementioned steps. This empirical process is based on a generalto-specific approach by eliminating individual lags in order to minimize AIC. Results and estimation coefficients are presented in column 1 of Table 2. Tests of linear specifications of the model affirm that no flaw is found and fitness of the model is rather high with $\mathrm{R}^{2}=$ 0.7424. Estimation results from the linear model show that currency devaluation affects the output after two quarters.

\section{Table 1: Linear Test Based on STR Specification}

\begin{tabular}{ccc}
\hline Transition variable & p-value & Model specification \\
\hline Trend & $1.6766 \mathrm{e}-01$ & Linear \\
$\Delta \mathrm{y}_{\mathrm{t}-1}$ & $1.6211 \mathrm{e}-02$ & LSTR2 \\
$\Delta \mathrm{y}_{\mathrm{t}-2}$ & $2.1432 \mathrm{e}-03$ & LSTR1 \\
$\Delta \mathrm{y}_{\mathrm{t}-3}$ & $7.6766 \mathrm{e}-04$ & LSTR2 \\
$\Delta \mathrm{y}_{\mathrm{t}-4}$ & $3.4737 \mathrm{e}-04$ & LSTR1 \\
\hline$\Delta \mathrm{g}_{\mathrm{t}}$ & $2.2492 \mathrm{e}-02$ & LSTR2 \\
$\Delta \mathrm{g}_{\mathrm{t}-1}$ & $2.1313 \mathrm{e}-02$ & LSTR2 \\
$\Delta \mathrm{g}_{\mathrm{t}-2}$ & $3.8443 \mathrm{e}-02$ & LSTR1 \\
\hline$\Delta \mathrm{m}_{\mathrm{t}}$ & $1.745 \mathrm{e}-04 *$ & LSTR1 \\
$\Delta \mathrm{m}_{\mathrm{t}-1}$ & $6.1153 \mathrm{e}-02$ & Linear \\
$\Delta \mathrm{m}_{\mathrm{t}-2}$ & $1.2492 \mathrm{e}-02$ & LSTR1 \\
\hline$\Delta \mathrm{e}_{\mathrm{t}}$ & $5.5664 \mathrm{e}-01$ & Linear \\
$\Delta \mathrm{e}_{\mathrm{t}-1}$ & $3.5409 \mathrm{e}-02$ & LSTR1 \\
$\Delta \mathrm{e}_{\mathrm{t}-2}$ & $8.6211 \mathrm{e}-02$ & Linear \\
\hline
\end{tabular}

Note: The result of model specification is based on minimum p-value

Table 1 shows p-values of linear tests performed on the specified linear model. The minimum p-value implies that the hypothesis of linearity is strongly rejected, and the LSTR1 model is chosen by comparing p-values of H2, H3, and H4. Though linear tests prove that 
the most transition variables have their values, and selecting transition variables may lead to various types non-linear models, Edwards's theoretical model (1) gives some implications about the role of money supply in the relationship between devaluation and output, so $\Delta \mathrm{m}_{\mathrm{t}}$ is chosen as STR's transition variable for estimating LSTR1 model.

Table 2 presents values of $\mathrm{G}$ and $\mathrm{C}$ when minimizing residual sum of squares during grid search process. The slope parameter $\gamma$ equal to 8.14 reflects a rather smooth transition from a period of low growth of money supply $(\mathrm{G}+0)$ to a period of higher growth of money supply $(\mathrm{G}=1)$. The coefficient $\mathrm{C}$ equal to 24.46 stipulates the threshold of money supply growth whereby impacts of variables on the output experience a transition step, that is, the nature of relationships between variables changes from that threshold. The following remarks could be drawn from the results in Table 2:

- Government spending $(\Delta \mathrm{g})$ : This variable bears a positive sign when the money supply growth is low $(\mathrm{G}=0)$ and a negative one when the growth is high $(\mathrm{G}=1)$. The total impact from these coefficients $\Delta \mathrm{g}_{\mathrm{t}-2}$ on the economic growth is -0.232 implying that the output is contracted when government spending increases.

- Real exchange rate $(\Delta \mathrm{e})$ : This variable bears a positive sign in the period of low growth of money supply and a negative one when the growth rate is high. The total impact of coefficient $\Delta \mathrm{e}_{\mathrm{t}-2}$ on output growth is +0.357 implying that economic activities may be improved in a period of depreciation. This impact, however, only takes place when the growth rate of money supply is lower than $24.46 \%$.

- Money supply $(\Delta \mathrm{m})$ : This variable and its lags bear negative signs in the period of low growth of money supply $(\mathrm{G}=0)$ and a positive one when the growth rate is high $(\mathrm{G}=1)$. The total impact of this variable with a lag equaling two quarters on output growth is +0.157 implying that increases in money supply positively affect the economic growth.

The result of STR model estimation is showed in the following equation (numbers in parentheses are t-ratio):

$$
\begin{aligned}
& \mathrm{Dy}=\underset{(2.0768)}{0.12173}-\underset{(-1.7688)}{0.0023921^{\prime}} \mathrm{Dy} \mathrm{t}_{\mathrm{t}-2}-\underset{(-1.774)}{0.75534^{\prime} \mathrm{Dyt}-3}+\underset{(-3.2666)}{0.68316^{\prime}} \mathrm{Dyt}-4+\underset{(2.1210)}{0.08486^{\prime}} \mathrm{Dg}_{\mathrm{t}-2} \\
& \text { - 0.07868' } \mathrm{Dm}_{\mathrm{t}}-0.56389^{\prime} \mathrm{Dm}_{\mathrm{t}-1}-1.8466^{\prime} \mathrm{Dm}_{\mathrm{t}-2}-2.22570^{\prime} \mathrm{De}_{\mathrm{t}-2}+\left[-0.36570^{\prime} \mathrm{Dyt}-2\right. \\
& (-1.8749) \quad(-2.6143) \quad(-1.5748) \quad(-1.85438) \quad(-1.8438) \\
& \left.+0.82954^{\prime} \mathrm{Dy} t-3-0.80778^{\prime} \mathrm{Dy} t-4-0.31731^{\prime} \mathrm{Dg}_{\mathrm{t}-2}+2.00369^{\prime} \mathrm{Dm}_{\mathrm{t}-2}+2.69631^{\prime} \mathrm{De}_{\mathrm{t}-2}\right]^{\prime} \\
& \stackrel{(1.7191)}{(-3.3847)}(-1.8008)
\end{aligned}
$$

The results of estimation of linear and non-linear models support the hypothesis about positive impacts on currency devaluation on output growth. STR model, however, produces findings different from those detected by linear model by showing that impact of currency 
devaluation on economic growth is strong when the money supply growth is lower than $24.46 \%$ as evident by the negative signs of the regression coefficients.

The results of all diagnostic and goodness-of-fit tests are also presented in Table 2. The diagnostic tests do not add any relationships in the specified linear model; all hypotheses of autocorrelation are rejected; and parameters do not change. Moreover, p-values of LM test for $\mathrm{ARCH}(8)$ and Jarque-Bera test show that the chosen model is appropriate.

Table 2: Result of Linear Model Estimation and Two-Regime LSTR1 Model of GDP Growth

\begin{tabular}{|c|c|c|c|}
\hline $\begin{array}{c}\text { Transition } \\
\text { variable }\end{array}$ & Linear model & $\begin{array}{c}\text { LSTR1 } \\
\text { G=0 }\end{array}$ & $\begin{array}{c}\text { Model } \\
\mathbf{G}=1\end{array}$ \\
\hline Intercept & $\begin{array}{l}0.07137 \\
(3.5414)\end{array}$ & $\begin{array}{l}0.12173 \\
(2.0768)\end{array}$ & \\
\hline \multicolumn{4}{|l|}{$\Delta \mathrm{y}_{\mathrm{t}-1}$} \\
\hline$\Delta \mathrm{y}_{\mathrm{t}-2}$ & $\begin{array}{c}-0.5701 \\
(-6.5806)\end{array}$ & $\begin{array}{c}-0.0023921 \\
(-1.7688)\end{array}$ & $\begin{array}{l}-0.36570 \\
(-1.8438)\end{array}$ \\
\hline$\Delta \mathrm{y}_{\mathrm{t}-3}$ & $\begin{array}{c}-0.5032 \\
(-6.0501)\end{array}$ & $\begin{array}{c}-0.75534 \\
(-1.774)\end{array}$ & $\begin{array}{c}0.82954 \\
(1.7191)\end{array}$ \\
\hline$\Delta \mathrm{y}_{\mathrm{t}-4}$ & $\begin{array}{c}-0.5164 \\
(-5.5775)\end{array}$ & $\begin{array}{l}0.68316 \\
(3.2666)\end{array}$ & $\begin{array}{l}-0.80778 \\
(-3.3847)\end{array}$ \\
\hline \multicolumn{4}{|l|}{$\Delta \mathrm{g}_{\mathrm{t}}$} \\
\hline \multicolumn{4}{|l|}{$\Delta \mathrm{g}_{\mathrm{t}-1}$} \\
\hline$\Delta \mathrm{g}_{\mathrm{t}-2}$ & $\begin{array}{c}0.1315 \\
(1.7462)\end{array}$ & $\begin{array}{l}0.08486 \\
(2.1210)\end{array}$ & $\begin{array}{l}-0.31731 \\
(-1.8008)\end{array}$ \\
\hline$\Delta \mathrm{m}_{\mathrm{t}}$ & $\begin{array}{c}-1.4367 \\
(-1.7281)\end{array}$ & $\begin{array}{l}-0.07868 \\
(-1.8749)\end{array}$ & \\
\hline$\Delta \mathrm{m}_{\mathrm{t}-1}$ & $\begin{array}{c}-0.6679 \\
(-4.3135)\end{array}$ & $\begin{array}{l}-0.56389 \\
(-2.6143)\end{array}$ & \\
\hline$\Delta \mathrm{m}_{\mathrm{t}-2}$ & $\begin{array}{c}-1.9930 \\
(-1.5510)\end{array}$ & $\begin{array}{c}-1.8466 \\
(-1.5748)\end{array}$ & $\begin{array}{l}2.00369 \\
(1.7115)\end{array}$ \\
\hline
\end{tabular}

$\Delta e_{t}$ 


\begin{tabular}{|c|c|c|c|}
\hline \multicolumn{4}{|l|}{$\Delta \mathrm{e}_{\mathrm{t}-1}$} \\
\hline$\Delta \mathrm{e}_{\mathrm{t}-2}$ & $\begin{array}{c}0.8178 \\
(5.6643)\end{array}$ & $\begin{array}{c}2.479732 \\
(1.7688)\end{array}$ & $\begin{array}{c}-2.12265 \\
(-1.84538)\end{array}$ \\
\hline Transit. Vb & & & $\Delta \mathrm{mt}$ \\
\hline$\gamma / \mathrm{c}$ & & $\begin{array}{c}\gamma=8.13643 \\
{[4.698127]}\end{array}$ & $\begin{array}{c}c=-24.4634 \\
{[-0.0153]}\end{array}$ \\
\hline \multicolumn{4}{|l|}{ Goodness } \\
\hline SD of resid & & 0.036 & \\
\hline $\mathrm{R}^{2}$ & 0.7424 & 0.92187 & \\
\hline $\mathrm{AIC} / \mathrm{SC}$ & $-5.09 /-5.56$ & $-7.83 /-6.12$ & \\
\hline \multicolumn{4}{|c|}{ Diagnostics (p-values) } \\
\hline Autocorr (8) & 0.3413 & 0.7951 & \\
\hline Normality & 0.5976 & 0.7334 & \\
\hline $\mathrm{ARCH}(8)$ & 0.8745 & 0.5876 & \\
\hline Constancy & & 0.5571 & \\
\hline Nonlinearity & & Not computed & (inversion problem) \\
\hline
\end{tabular}

Note: $t$-statistics value in parentheses

\section{CONCLUSION OF IMPACTS OF CURRENCY DEVALUATION ON THE ECONOMIC GROWTH DURING 2000-2012}

In the context of modeling of STR based on the most possibly reliable data from GSO and IMF, the authors can draw some conclusions about impacts of devaluation on economic growth.

- Past empirical researches on currency devaluation based on traditional time series models usually make assumptions about linear relationships, and thus cannot reflect fully relationships of macroeconomic variables, especially when other variable also produce effects on output. Meantime, the STR model represents an approach that takes into account impacts of money supply through a non-linear function. Specifically, the paper reaches a conclusion that currency devaluation may help increase the output if the growth of money supply is below $24.46 \%$. When the money supply growth is above this threshold, currency devaluation can contract the output.

Comparing quantitative results with currency devaluation and its impacts on the growth in Vietnam in 2000-2012 shows that: 
- After the Asian financial crisis in 1997-1998, Vietnam adopted a crawling peg regime. The exchange rate of the VND to US dollar was kept stable for a long time. From Q1 of 2000 to Q3 of 2009, depreciation of the VND against the dollar was always lower than $1 \%$ per quarter while the money supply growth was very high, over $26.5 \%$ on average. Currency devaluation, therefore, might produce some effects on economic growth but they were not serious because the depreciation is low.

- In the recent period of macroeconomic imbalance, depreciation of the VND against US dollar was rather high, amounting to $24 \%$ in the period from Q4 of 2009 to Q2 of 2011. This figure was 5.04\%; 9.35\% and 3,64\% in Q1/2010, Q1/2011 and Q2/2011 respectively, while the money supply growth, especially in the period from Q3/2010 to Q1/2011, was also pretty high as compared with corresponding periods $(26.5 \% ; 29.7 \%$ and $25.9 \%$ respectively) accompanied by high depreciation rates. According to the GSO, the 2011 growth rate fell to $5.8 \%$ from $6.8 \%$ in 2010 . It could be concluded that the fall in GDP growth rate might be affected by currency depreciation.

- From Q3/2011 onwards, a tight money policy was adopted to ensure macroeconomic stability. In 2012, the VND/USD exchange rate even fell by $0.96 \%$ compared with 2011 . In the context of prolonged macroeconomic imbalance, this could be seen as a success in stabilizing public mentality and curbing the inflation. When the exchange rate is pegged, the money supply rises and credit growth is low (20\% and $7 \%$ respectively), and the growth rate decreases $(5.03 \%)$, adopting a fixed exchange rate is not completely reasonable.

\section{RECOMMENDATIONS ON SOLUTIONS}

In our opinion, SBV could take the following measures in 2013:

(i) Increasing the band on either sides of the exchange rate to $\pm 3 \%$ to make the exchange rate and foreign exchange market compliant to signs from the market. The suggested band is the one adopted by SBV before it depreciated the domestic currency by $9.3 \%$ and contract the band from $\pm 3 \%$ to $\pm 1 \%$ on Feb. 11, 2011 .

(ii) Devaluating the domestic currency gradually to support economic growth ensuring the targeted growth rate of 5.5\%. We suggest an average depreciation rate in 2013 over 2012 of $3-5 \%$.

(iii) To support the growth while devaluating the currency, the money supply growth should be kept below $24.46 \%$ as suggested by research findings. Because money supply growth comprises credit growth and change in net foreign assets, we suggest keeping credit growth in commercial banks in the range from $12 \%$ to $15 \%$ in compliance with changes in 
macroeconomic situation. This suggestion is based on strong increases in Vietnam's net foreign assets in 2012 and its potential for future rises

\section{References}

Ahmed, S. (2003), "Sources of Economic Fluctuations in Latin America and Implications for Choice of Exchange Rate Regimes,” Journal of Development Economics, 72, 181-202.

Bahmani-Oskooee, M. \& I. Miteza (2003), “Are Devaluations Expansionary or Contractionary? A survey Article", Economic Issues, Vol. 8, Part 2

Bahmani-Oskooee, M. \& I. Miteza (2006), "Are Devaluations Contractionary? Evidence from Panel Cointegration”, Economic Issues, Vol. 8, Part 2.

Brüggemann, R. \& H. Lütkepohl (2001), "Lag Selection in Subset VAR Models with an Application to a U.S. Monetary System,” in R. Friedmann, L. Knüppel \& H. Lütkepohl (eds.), Econometric Studies: A Festschrift in Honour of Joachim Frohn, LIT Verlag, Münster, 107-128.

Chou, W.L, \& C-C. Chao (2001), "Are Currency Devaluations Effective? A Panel Unit Root Test." Economics Letters, 72, 19-25.

Edwards, S. (1989), Real Exchange Rates, Devaluation, and Adjustment, MIT Press, Cambridge, MA.

Gács, J. (2003), “Transition, EU Accession and Structural Convergence,” Empirica, 30, 271-303.

Halpern, L. \& C. Wyplosz (1997), “Equilibrium Exchange Rates in Transition Economies,” IMF StaffPapers, 44, December, 430-461.

Lê Quốc Lý (2004), Tỉ giá hối đoái - nhũng vấn đề lí luận và thực tiễn điều hành ở Việt Nam, Thống kê Publisher, Hà Nội.

Lê Văn Tư \& Nguyễn Quốc Khanh (2000), Một số vấn đề về chính sách ti giá hối đoái cho mục tiêu phát triển kinh tế ở Việt Nam, Thống kê Publisher, Hà Nội.

Mejia-Reyes, P., D. Osborn \& M. Sensier (2003), "Modeling Real Exchange Rate Effects on Growth in Latin America", Discussion paper series / Centre for Growth and Business Cycle.

Miteza, Ilir (2006), "Exchange Rates and Non-Linear Dynamics in Output: Evidence from Bulgaria”, Journal of Economics and Business, Vol. IX - 2006, No 1 (91-115).

Nguyễn Khắc Minh (2009), "Cơ sở lí thuyết chuỗi thời gian phi tuyến và ứng dụng vào xây dựng mô hình phân tích lạm phát cho Việt Nam”, a report within the European Technical Assistance Programme for Vietnam, Component 5: Statistical Analysis and Policy Tools at the MPI.

Terasvirta, T. (2004), "Smooth Transition Regression Modelling," in H. Lütkepohl \& M. Krätzig (eds.), Applied Time Series Econometrics, Cambridge University Press, Cambridge, 222-242.

Vũ Quốc Huy, Nguyễn Thị Thu Hằng \& Vũ Phạm Hải Đăng (2012), “Tỷ giá hối đoái giai đoạn 2000-2011: Các nhân tố quyết định, mức độ sai lệch và tác động đối với xuất khẩu”, Tri thức Publisher. 